\title{
MEMPERTIMBANGKAN KEMBALI ORIENTASI GERAKAN BANTUAN HUKUM DI INDONESIA
}

\author{
Herlambang P. Wiratraman \\ email: herlambang@fh.unair.ac.id
}

\begin{abstract}
This article discusses the practice of individual and structural legal aid and how it has been contextualized within the dynamic of Indonesian politics and law making (especially related to Law No. 16 of 2011 re. Legal Aid). The main question addressed is the extent to which legal aid succeed in pushing real legal reform and contribute to the effort of realizing a just society. Unfortunately, the author discovers that legal reform initiated post Soeharto, initially held to be positive, failed to fulfills its intended goals. Instead law implementation and enforcement remains vulnerable to external pressure and in fact had been unable to stop on-going human rights violations and widespread corruption.
\end{abstract}

Keywords: legal aid movement. social change. legal aid institutions.

\begin{abstract}
Abstrak
Artikel ini mendiskusikan praktik serta pengalaman pemberian bantuan hukum individual maupun struktural yang dihadapkan pada realitas politik hukum Indonesia bertitik tolak dari UndangUndang No. 16 tahun 2011 tentang Bantuan Hukum. Pertanyaan utama di sini ialah seberapa jauh bantuan hukum berhasil mendorong perubahan sosial yang berkeadilan? Untuk itu semangat reformasi hukum yang dicanangkan dan juga diperjuangkan lembaga-lembaga bantuan hukum ditelaah dari perspektif realita sosial politik Indonesia. Satu temuan penting ialah reformasi hukum yang 'dinilai positif' ternyata justru melahirkan situasi yang tidak jauh berbeda dengan kondisi masa Soeharto, di mana hukum masih begitu gampangnya dilemahkan, diskriminatif dan berkarakter melegitimasi pelanggaran HAM dan korupsi.
\end{abstract}

Kata kunci: gerakan bantuan hukum. perubahan social. lembaga bantuan hukum.

\section{Pengantar}

This is frontier capitalism that thrives on low wages and high exploitation.

When neo-liberalism in the Global South fails to bring development and produces income polarization, it's not because of the failure of neo-liberalism but because if its success.

It's not because of the 'politics of structural reform', but because of structural reform itself. ${ }^{1}$

${ }^{1}$ Jan Naderveen Pieterse. Globalization or Empire?, Routledge, New York/London, 2004, hlm. 12. 
Dalam dua dekade terakhir, persoalan dominan yang mempengaruhi pengembangan kebijakan dan politik-ekonomi di negara-negara Selatan, termasuk Indonesia, adalah globalisasi Neo-Liberal. Rejim pemerintah otoritarian di Asia yang bertumbangan di akhir 1990an, tak mengubah situasi itu, bahkan sebaliknya, kian mengukuhkan arah kebijakan dan politik ekonomi negara-negara tersebut. Betul bahwa rejim pemerintahan Indonesia sekarang ini telah bergeser menjadi 'lebih demokratis' di beberapa bidang tertentu. Dapat disebut berkembangannya demokrasi elektoral dan terakomodasinya tuntutan atas penghormatan dan pengakuan hak-hak asasi manusia dalam hukum. Namun, skenario global yang mendominasi telah menancapkan siasat politik-ekonomi yang berbasis pada mekanisme dan kebebasan pasar, dan berhasil melemahkan dan menundukan rejim-rejim yang dipercaya 'lebih demokratis' tersebut.

Akibatnya, di tengah transisi politik demokratisasi, kita menyaksikan praktik eksploitasi yang kian masif dan sistematik, baik terhadap manusia maupun sumber daya alam. Pemerintah, sebagai elit politik (pemegang kekuasaan formal) dalam perjumpaan dengan pemilik modal yang menjadi penggerak politik lokal-nasional, berkembang dan sekaligus mewujudkan diri menjadi politik elit yang justru cenderung menjadi predatorik dan begitu mudah melindas kepentingan rakyat dan hak-hak asasi manusia. Tidak mengherankan bilamana kebijakan, peraturan perundang-undangan, penegakan hukum, bahkan bisa dikatakan keseluruhan sistem hukum, mengalami kemandekan, akibat pengaruh sistem politik hukum yang diskriminatif, eksploitatif, nan koruptif.

Situasi di atas memaksa lembaga-lembaga bantuan hukum, baik yang berbasiskan kampus maupun di luar kampus, menegaskan kembali posisinya sebagai bagian gerakan masyarakat sipil. Berkaitan dengan ini dapat dicermati adanya pergeseran pola dan strategi bantuan hukum, dari orientasi bantuan hukum untuk rakyat miskin, kemudian bergeser menjadi gerakan bantuan hukum structural. ${ }^{2}$

2 Todung Mulya Lubis. Bantuan Hukum dan Kemiskinan Struktural (LP3ES, Jakarta, 1986); Todung Mulya Lubis. "Gerakan Bantuan Hukum Di Indonesia: Sebuah Studi Awal" dalam Abdul Hakim 
Kiranya di sini penting dikritisi: apakah orientasi pergerakan tersebut sekarang ini masih relevan mengingat konteks persoalan dan tantangan sosial politik Indonesia yang juga terus berubah.

Dapat dikatakan bahwa kiprah lembaga-lembaga bantuan hukum pasca Soeharto justru terjebak masuk ke dalam program-program yang meneguhkan posisi imperialisme neo-liberal yang tidak hanya memarjinalisasi, tetapi justru menghambat pergerakan sosial yang efektif. Tidak mengherankan bilamana organisasi atau lembaga-lembaga tersebut menjadi lebih sibuk dengan menjalankan program-program yang difasilitasi lembaga-lembaga donor dan sebab itu justru menghabiskan waktu berurusan dengan standar laporan, output kerja, serta pola-pola organisasi kerja. Dengan cara itu agenda kerja lembaga-lembaga bantuan hukum ternyata diarahkan dan didisplinkan oleh kekuatan-kekuatan eksternal. Pada dasarnya, pendisiplinan organ-organ pergerakan lembagalembaga bantuan hukum melalui cara-cara di atas melemahkan posisi dan peran yang seharusnya diemban lembaga itu di tengah perubahan sosial yang begitu cepat.

Dalam konteks itulah perlu bagi lembaga-lembaga bantuan hukum untuk melakukan reorientasi agar ikhtiar pemberian bantuan hukum dapat secara lebih efektif mendorong transformasi sosial politik yang berkeadilan. Pertanyaan kunci di sini, mengapa gerakan bantuan hukum struktural perlu ditinjau ulang. Tidak hanya dalam kaitan dengan lima tahun pasca pemberlakuan Undang-Undang Bantuan Hukum, melainkan karena tumbuh-kembangnya politik ekonomi hukum yang kuat berwatak neoliberalisme dan predatorisme lokal pasca politik desentralisasi. Di samping itu berkaitan dengan itu perlu juga disinggung

Garuda Nusantara dan Mulyana W. Kusumah, Beberapa Pemikiran Mengenai Bantuan Hukum: Ke Arah Bantuan Hukum Struktural (Alumni, Bandung, 1990); Todung Mulya Lubis. "Bantuan Hukum: Arah dan Peranannya", Prisma No. 6 Tahun II, Desember 1973; Adnan Buyung Nasution. Bantuan Hukum di Indonesia. (LP3ES, Jakarta, 1981); Moch Zaidun. "Gerakan bantuan hukum struktural di Indonesia: studi tentang tipologi gerakan bantuan hukum struktural Yayasan LBH Indonesia". M.Si. Tesis. Surabaya: Program Pascasarjana, Universitas Airlangga, 1996. 
bagaimana imajinasi gerakan bantuan hukum menyasar 'perubahan sosial yang berkeadilan'.

\section{Pemiskinan Struktural dan Pergeseran Bantuan Hukumnya}

Apa yang terjadi di Indonesia sekarang ini, yaitu pemiskinan struktural yang meluas dan sistemik, tidak bisa dimengerti terlepas dari konteks perkembangan pembaruan hukum perburuhan di Indonesia pasca krisis finansial. Setidaknya terjadi tiga gelombang pembaruan hukum (1997-1998, 2000-2004, dan 2005-sekarang). ${ }^{3}$ Namun dalam proses itu ditengarai pengaruh kuat dari kekuatan Neo-Liberalisme yang bekerja melalui tangan-tangan multilateral development banks (Bank-bank pembangunan multilateral, semacam Bank Dunia, Bank Pembangunan Asia, dan IMF). Lembaga-lembaga ini tampaknya turut terlibat merancang arah perkembangan hukum perburuhan.

Sebagaimana mudah disaksikan skema pembaruan yang diusung proponen neo-liberal begitu gampang dipercaya pemerintah negara-negara di Selatan yang mayoritas adalah negara miskin dan berkembang, tak terkecuali Indonesia. Skema itu mencipta skenario kebijakan perburuhan, antara lain: good governance (tata pemerintahan yang baik), labor market flexibility (pasar buruh lentur), dan legal framework for development (kerangka hukum untuk pembangunan). Untuk memastikan wacana-wacana di atas mudah diterima, termasuk oleh kelompok pro-demokrasi, maka diperlukan bantuan dan dukungan teknologi kekuasaan dan rasionalitas, yaitu dalam wujud pemenuhan persyaratan utang, bantuan teknis, dan utang itu sendiri. Turunan-turunan diskursus tersebut dikembangkan untuk memberikan pembenaran atas politik hukum yang dijadikan acuan dan sekaligus dilengkapi dengan alasan-alasan lain seperti pentingnya merespon kebutuhan

\footnotetext{
3 Herlambang P. Wiratraman. "Disain Neo-Liberalisme dan Ancaman Terhadap Hak-Hak Buruh", Makalah Untuk Labor Law Course For Trade Unionist, Training, Surabaya, 7-10 September 2006, Trade Union Rights Center Dan Forum Buruh Surabaya (2006); Herlambang P. Wiratraman. Good Governance and Legal Reform in Indonesia. (OHRSD Mahidol University, Bangkok, 2007).
} 
investasi pasca krisis, pengentasan kemiskinan, pengurangan pengangguran, dan penciptaan hubungan industrial yang kondusif.

Kesemua itu melandasi ikhtiar reformasi kebijakan buruh seperti tiga paket perundang-undangan hukum perburuhan (UU No. 21 Tahun 2000 tentang Serikat Buruh; UU No. 13 Tahun 2003 tentang Ketenagakerjaan dan UU No. 2 Tahun 2004 tentang Penyelesaian Perselisihan Hubungan Industrial/PPHI). ${ }^{4}$ Alhasil, pengembangan dan pelaksanaan paket kebijakan hukum perburuhan itu sebaliknya muncul sebagai mesin penggilas hak-hak rakyat dan juga memberangus gerakan buruh maupun aktifis organisasi non-pemerintah.

Perubahan politik hukum (perburuhan) seperti digambarkan di atas bukanlah hal baru. Hal ini sudah pernah terjadi di masa pemerintahan Soeharto. Namun yang berbeda adalah skenario pematerialisasian pelanggaran hak-hak asasi manusia yang dilegalkan (legalized human rights violation). Ini justru terjadi dengan melalui sarana demokrasi, yang berpusat pada perancangan sistem demokrasi yang dibuat ramah terhadap kepentingan neo-liberalisasi kapital. Demokrasi dalam konteks itu justru muncul sebagai sarana untuk mendisplinkan dinamika politik ekonomi dan ditujukan untuk menyingkirkan dan melemahkan hak-hak rakyat. Tak heran, bila dari sudut pandang ketatanegaraan, lahir sejumlah lembaga-lembaga negara baru dari rahim neo-liberalisme, baik dalam lingkup kekuasaan eksekutif maupun yudisial. UU No. 2 Tahun 2004 tentang Penyelesaian Perselisihan Hubungan Industrial (PPHI) adalah salah satu contoh bagaimana tekanan politik liberal berpengaruh terhadap pengembangan institusi peradilan baru. Praktiknya, bukannya Negara berupaya melindungi dan memenuhi hak-hak normatif buruh. Sebaliknya dengan model itu, Negara justru membiarkan buruh dalam mekanisme pasar liberal berhadapan dan berlawanan dengan pemilik modal di pengadilan. Situasi di atas diperburuk oleh menguatnya oligarki politik

4 Herlambang P. Wiratraman. Good Governance and Legal Reform in Indonesia. (OHRSD Mahidol University, Bangkok, 2007). 
lokal yang menumbuh-suburkan kekuatan elit-elit predatoris pasca politik desentralisasi di era reformasi. ${ }^{5}$

Dengan kesadaran penuh adanya perkembangan situasi yang digambarkan di atas, sejumlah lembaga bantuan hukum yang ternaung dalam organisasi payung: Yayasan Lembaga Bantuan Hukum Indonesia (YLBHI), merancang strategi untuk mengubah itu semua. Langkah pertama adalah dengan mengevaluasi sejauh mana gerakan bantuan hukum struktural yang telah satu dekade lebih dikembangkan masih relevan untuk menanggapi perkembangan dan perubahan sosial-politik-ekonomi yang terjadi. Silang pendapat tentang itu terpetakan dalam kegelisahan pemikiran yang dituangkan ke dalam Buku Panduan Bantuan Hukum yang diterbitkan YLBHI pada 2014.6 Kendati demikian, ikhtiar ini saja tampaknya belum cukup kuat untuk mendorong transformasi pergerakan, perlawanan terhadap arah kebijakan politik ekonomi, apalagi mengubah program-program strategis bantuan hukum yang dicanangkan lembaga-lembaga bantuan hukum yang ada. ${ }^{7}$

Padahal program-program strategis yang dikembangkan sesungguhnya sudah terencana dengan baik. Program-program itu sudah sekaligus menempatkan posisi bantuan hukum yang dikombinasikan dengan program melek hukum (legal literacy), yang mencakup kegiatan pendidikan di kampung-kampung, sebagai upaya mengembangkan kapasitas masyarakat, seperti program-program paralegal atupun pos bantuan hukum. Sedangkan legal literacy, sebagaimana ditulis oleh Wignjosoebroto ${ }^{8}$ dan Siahaan ${ }^{9}$ adalah upaya membangun kesadaran

5 Gerry Van Klinken and E. Aspinall. The state and illegality in Indonesia. (Brill, Leiden, 2011); Vedi R. Hadiz. "Local Power: Decentralization and political reorganization in Indonesia," conference paper, presented at the "Globalization, Conflict, and Political Regimes in East and Southeast Asia," (Asia Research Center, Murdoch University, Western Australia, 15-16 August 2003); Vedi R Hadiz. "The Localization of Power in Southeast Asia," Democratization, 14:5, 873-892, (2007); Vedi R. Hadiz. Localising Power in Post-Authoritarian Indonesia: A Southeast Asia Perspective. (Stanford University Press, Stanford, 2010).

6 Herlambang P. Wiratraman dan M. Yasin (ed) Panduan Bantuan Hukum di Indonesia (AusaidYLBHI, Jakarta, 2014)

7 Id.

8 Soetandyo Wignjosoebroto, Hukum dalam Masyarakat, Graha Ilmu, Yogjakarta, 2013. 
hukum sekaligus gerakan pemberantasan buta hak, 'program untuk membikin warga melek hukum'. Artinya tujuannya tidak hanya sebatas menyadarkan orang akan hadirnya suatu undang-undang dalam kehidupan berikut kewajiban apa saja yang menurut undang-undang itu harus dipenuhi warga. Lebih jauh dari itu, program melek hukum ini ditujukan sebagai ikhtiar mengkritisi dan memperkuat posisi dan gerakan masyarakat. Sebagaimana disebutkan Margaret Schuler dan Kadirgam-Rajashingham dalam Wignyosoebroto, ${ }^{10}$ mereka mendefinisikan legal literacy sebagai "(the) acquiring of critical awareness about rights and the law, the ability to asserts rights, and the capacity to mobilize for change".

Melalui itu hendak diajukan gagasan advokatif yang baru tentang hukum sebagai kekuatan politik yang diharapkan mampu menggerakkan roda perubahan yang lebih memihak kepentingan golongan rakyat yang selama ini termarjinalisasi. Menurut Wignjosoebroto, ${ }^{11}$ legal literacy bukanlah sekadar gambaran laten tentang status kogninitif seseorang, melainkan benar-benar suatu proses sosio-politik yang manifes. Inilah proses yang sengaja direncanakan dan diupayakan secara sistematis untuk membangunkan kesadaran warga dalam rangka menggalakkan upaya memberantas buta hak sekaligus menyeimbangkan kekuatan tawar antara mereka yang berposisi marjinal (karena buta hukum dan buta hak) dengan penguasa.

Melek hak (bukan semata melek hukum) diupayakan menjadi jawaban untuk melawan dan menangkal proses marjinalisasi atau penyingkiran hak-hak, termasuk bekerjanya pemiskinan sistematik. Sekalipun demikian, dalam relasi kekuasaan yang timpang dan terus direproduksi oleh hukum, muncul persoalan apakah melek hukum saja cukup untuk mendorong perubahan relasi sosial dan kekuasaan?

9 Herbin M. Siahaan (ed.). Pemberdayaan Hukum Untuk Meningkatkan Tata Pemerintahan Yang Baik Dan Mengurangi Kemiskinan (The Asia Foundation dan Asian Developing Bank, Jakarta, 2003).

${ }^{10} \mathrm{Id}$.

${ }^{11} \mathrm{Id}$. 


\section{'Legal Reform', 'Good Governance' dan 'Access to Justice' LBH dalam Kepungan Mantra Politik Hukum?}

Ada sejumlah catatan yang diberikan sehubungan dengan perjuangan LBH (lembaga bantuan hukum) sebagai pembela kepentingan rakyat miskin. Catatan itu antara lain, berkaitan dengan keterlibatan masyarakat sipil dalam setidaknya tiga persoalan besar: legal reform [pembaruan hukum], good governance [tata kelola pemerintahan yang baik), access to justice [akses terhadap keadilan]. Ketiganya, sebagai mantra, banyak diucap dan menjadi panduan kerja lembagalembaga bantuan hukum ketika mengembangkan skema proyek atau program kerja mereka, termasuk ke dalamnya perancangan model-model pendidikan hukum (kritis), paralegalisme, dan pelatihan-pelatihan serta seminar kolaboratif. Sekilas, program atau proyek-proyek pembaruan hukum yang disertai diskursus good governance dan akses keadilan sertamerta terkesan baik karena keduanya dilekati konsep good (baik) dan justice (keadilan). Problem besarnya adalah, secara konseptual, keduanya tetap perlu dicermati dan ditelaah lebih lanjut. Satu hal penting adalah memastikan bagaimana good governance itu betul good dan apakah akses keadilan benar berhasil mewujudkan keadilan.

Dalam konteks itu dapat dipertanyakan apakah upaya mewujudkan transparansi informasi yang dicanangkan pemerintahan daerah betul merupakan ikhtiar mendorong proses demokratisasi dan partisipasi publik? Bahkan kalangan awam akan cenderung menilai ada/tidaknya kemajuan dalam kaitan dengan proses demokratisasi. Namun begitu, bilamana dilakukan penelusuran lebih jauh seringkali tampak bahwa kebijakan transparansi yang dicanangkan pemerintah daerah - bahkan pemerintah pusat - tidak selamanya berkaitan dengan kebutuhan mewujudkan demokrasi atau meningkatkan partisipasi publik.

Dalam banyak kasus penyelesaian sengketa tanah (agraria), ternyata banyak lembaga bantuan hukum yang mendampingi petani kecil, masih kesulitan mendapatkan informasi yang diperlukan dan terbentur pada sikap kantor pertanahan atau Badan Pertanahan Nasional (BPN) di tingkat kabupaten/kota 
maupun propinsi tidak sertamerta terbuka memberikan dan menyampaikan informasi publik. BPN kerap menyembunyikan informasi yang berkaitan dengan [penyelesaian] sengketa tanah. Dalam satu kasus kasus sengketa tanah yang melibatkan kelompok petani yang tergabung dalam Organisasi Petani Wongsorejo Banyuwangi (OPWB), lembaga bantuan hukum yang menangani perkara ini kesulitan mendapatkan informasi tentang status hak guna usaha (HGU) PT. Wongsorejo. Kesulitan serupa dialami Komunikasi Petani Pantai Selatan Lumajang (Koppas) yang berkepentingan melacak status hak atas tanah yang secara fisik dikuasai TNI AD di pesisir selatan Lumajang.

Ilustrasi lain tentang gagalnya ikhtiar mewujudkan pemerintahan yang transparan dapat ditengarai dalam kasus persidangan yang memeriksa penolakan warga Gunem di Rembang atas pendirian pabrik semen, dikaitkan dengan penerbitan Surat Keputusan (SK) Gubernur Jawa Tengah Nomor 668.1/17 tahun 2012 tentang Izin Lingkungan Kegiatan Penambangan (7 Juni 2012) yang diberikan pada PT. Semen Gresik (Persero) Tbk (pada berikutnya diubah namanya menjadi PT. Semen Indonesia), di Kabupaten Rembang, Provinsi Jawa Tengah. Warga Gunem di Rembang mengajukan gugatan kehadapan Pengadilan Tata Usaha Negara. Pokok soal ialah permohonan pembatalan surat keputusan di atas karena dianggap melanggar banyak peraturan perundang-undangan (antara lain: UU No. 32 Tahun 2009 tentang Pengelolaan Lingkungan Hidup), dan sekaligus melanggar Asas-Asas Umum Pemerintahan yang Baik (AAUPB), termasuk diabaikannya pemberian akses informasi dan transparansi. ${ }^{12}$ Dalam putusan Peninjauan Kembali di Mahkamah Agung (Putusan No 99.PK/TUN/2016), gugatan TUN yang diajukan warga dimenangkan dan ini maknanya bahwa ijin lingkungan yang dibatalkan berkonsekuensi pada penghentian segala proses pembangunan dan rencana operasional pabrik. Namun, disayangkan fakta di lapangan justru menunjukan bahwa pejabat publik justru mengabaikan putusan

12 YLBHI-LBH Semarang, Catatan Akhir Tahun 2015: Membunyikan Lonceng Kematian (LBH Semarang, Semarang, 2015)., hlm. 7-8. 
Mahkamah Agung tersebut. Dalam konteks kasus tersebut, Gubernur Jawa Tengah (Ganjar Pranowo), justru mengeluarkan Surat Keputusan No. 660.1/30 Tahun 2016 tentang Izin Lingkungan Kegiatan Penambangan Bahan Baku Semen dan Pembangunan serta Pengoperasian Pabrik Semen PT Semen Indonesia (Persero) Tbk. di Kabupaten Rembang Provinsi Jawa Tengah.

Kasus layanan publik dalam konteks transparansi penyelesaian sengketa agraria dan sumberdaya alam nampaknya masih 'jauh panggang dari api.' Terjadi kesenjangan antara ideal kerangka aturan normatif dengan implementasi di lapangan. Tidak mengherankan, badan-badan pemerintahan sekalipun terus menggadang jargon good governance, justru menjadi bagian dari konflik dan dengan keberpihakannya itu terus menerus merugikan kepentingan publik secara luas.

Dapat dan perlu disebut di sini menguatnya korupsi sistematik di tingkat birokrasi politik lokal. Konspirasi politik lokal menyuguhkan fakta bertemunya pemodal, birokrasi dan institusi hukum yang selanjutnya melahirkan sistem impunitas dan pelemahan penegakan hukum. Alhasil, para (tersangka-terdakwa tindak pidana) korupsi maupun pelaku pelanggaran hak asasi manusia begitu mudahnya lolos dari jerat hukum. Ini semua adalah karena tata kelola pemerintahan yang baik hanya digunakan sebagai slogan politik. Tidak ada yang salah dengan gagasan itu sendiri. Tidak berjalannya tata kelola pemerintahan yang baik ini sebaliknya terjadi karena keberlakuan paradigm lama yang justru melestarikan watak kekuasaan politik yang cenderung korup dan diskriminatif.

Lebih celaka, ternyata gerakan masyarakat sipil, termasuk lembagalembaga bantuan hukum, tidak mampu keluar dari jebakan diskursus neo-liberalisme dan ekonomi pasar yang mendominasi. Mereka tidak lagi mampu melihat secara kritis dan tiba pada kesadaran atau pemahaman bahwa problema besar tidaklah ada pada level diskursus melainkan di tataran paradigma yang tidak juga berubah. Paradigma dominan dalam konteks ini adalah masih terus bekerjanya atau terimplementasinya gagasan good governance, access to justice 
dan lain sebagainya, yang tidak terlepas dan masih berpusat pada gagasan dan kebijakan liberalisasi pasar.

Tampaknya strategi neo-liberal yang bertujuan mempertahankan hegemoni adalah secara berkelanjutan mereproduksi pengetahuan soal rasionalitas good governance. Dengan cara itu, kekuasaan hegemonik dimudahkan bekerja melalui berbagai pintu masuk di level negara, non negara maupun kemitraan keduanya. Realitas yang kemudian muncul adalah dikontruksikannya wacana (diskursus) ketatapemerintahan, pembaruan hukum dan kebijakan publik seolah tidak terpisah dan berkelindan dengan gagasan demokrasi, hak asasi manusia, anti kemiskinan maupun antikorupsi. Kesemua itu pada akhirnya muncul sebagai perangkap yang total dikendalikan pendukung dan paham neo-liberal. Dengan cara itu pula, perhatian masyarakat dialihkan dari adanya ketidakseimbangan pembagian kekuasaan politik dan pemerintah. Lebih dari itu, arah reformasi yang diberi label good dibelokan melalui program-program pendanaan ke sejumlah institusi negara, organisasi non-pemerintah, serta kampus-kampus melalui pusat-pusat studi governance. Godaan untuk mengakses dana proyek governance terlampau besar. Tidak sedikit organisasi kemasyarakatan atau gerakan sipil terjebak dan menyesuaikan rencana dan pola kerja organisasinya hanya untuk mengejar dan mendapatkan access. Inilah yang dapat kita sebut gejala donor-driven hegemony!

\section{Penegakan Hukum Lumpuh, HAM Terabaikan}

Pengaruh paham neo-liberalisasi pada pembuatan maupun pelaksanaan hukum, mengakibatkan kemandegan penegakan hukum. Hal yang tidak terkecuali muncul dalam ketidakseriusan pemerintah memajukan maupun menegakan hakhak asasi manusia. Padahal seharusnya penegakan hukum tidak tertuju hanya pada penerapan hukum secara tegas semata. Namun lebih jauh lagi sejatinya mengupayakan pembangunan sistem hukum yang bekerja secara berkeadilan, tanpa diskriminasi, dan mampu menjangkau seluruh struktur politik 
ketatanegaraan dengan tujuan akhir menjamin penghormatan dan penegakan hak-hak dasar warga negara.

Satu masalah di sini yang menghalangi penegakan hukum yang dicita-citakan di atas adalah munculnya sejumlah palang pintu politik hukum. Dalam tulisan terpisah, telah diungkap bahwa ada setidaknya lima hambatan atau palang pintu politik di atas. ${ }^{13}$ Pertama, hukum dan penegakannya telah terlalu jauh masuk ke dalam pusaran kekuasaan politik ekonomi. Kedua, pemerintah tidak saja melakukan pembiaran, tetapi justru secara langsung terlibat dalam konflik dan kekerasan di masyarakat. Dalam hal ini yang terancam atau dikorbankan adalah jaminan untuk menikmati hak atas rasa aman warga masyarakat. Ketiga, dilanggengkannya impunitas. Para pelaku kejahatan hak asasi manusia tidak dapat dimintakan pertanggungjawaban hukum. Proses hukum, bila sudah mulai dijalankan, malah dibiarkan mengambang tanpa kejelasan. Pernyataan Jaksa Agung Basrief Arief perihal kasus pembunuhan aktivis hak asasi manusia, Munir, mengindikasikan kuatnya kebijakan impunitas. ${ }^{14}$ Keempat, melemahnya fungsi protektif yang seharusnya diemban lembaga-lembaga Negara: tersumbatnya aspirasi politik warga negara melalui parlemen, masih dominannya praktik mafia peradilan, dan ketidakberpihakan pemerintah pada penyelenggaraan dan pemajuan hajat hidup orang banyak. Kelima, terpasungnya kebebasan pers, hal mana terkait dominasi kendali pemilik media yang berkepentingan untuk mendapatkan akses atas kekuasaan politik, baik di level nasional maupun lokal.

Konflik sosial maupun kekerasan aparat Negara terhadap warganegara masih juga terus terjadi. Sebagai ilustrasi semasa pemerintahan Presiden Susilo Bambang Yudhoyono, begitu banyak petani - rakyat kecil - menjadi korban tindak kekerasan yang dilakukan aparat Negara akibat memperjuangkan dan memper-

\footnotetext{
${ }^{13}$ Herlambang P. Wiratraman, Gagalnya Penegakan Hukum dan HAM, Kompas, 30 September (2011)

${ }^{14}$ Kompas, 7 September 2011
} 
tahankan hak-hak mereka atas tanah yang dirampas (kasus Alas Tlogo di Pasuruan, penembakan di Bima, kasus Mesuji dan kasus Selok Awar-Awar Lumajang yang menewaskan Salim Kancil). Rangkaian peristiwa tersebut jelas merupakan tamparan keras bagi upaya dan perjuangan memajukan serta menegakkan hak asas manusia di Indonesia. Masyarakat umum seolah dibiarkan terus bertanya tentang kehadiran Negara dan apakah Negara sesungguhnya memiliki kewajiban melindungi hak-hak dasar warga negara.

Situasi serupa, buruknya penegakan hukum negara, juga muncul dalam penanganan kasus-kasus korupsi. Bahkan riuh rendahnya pemberitaan tentang konflik kewenangan antar dua lembaga negara (KPK vs PolRi) berkaitan dengan penanganan penyimpangan dalam proyek pengadaan simulator SIM, jelas menunjukkan situasi paling rendah dalam upaya pemajuan strategi penegakan hukum yang efektif. Selain itu, sasaran pelumpuhan penegakan hukum atas kasus-kasus korupsi adalah KPK (Komisi Pemberantasan Korupsi). Kriminalisasi terhadap Komisioner KPK, Bambang Widjojanto dan Abraham Samad. Tidak luput adalah tembakan hukum terhadap Komisioner Komisi Yudisial, Suparman Marzuki dan Taufiqurrohman Syahuri. Serangan ini muncul berkaitan dengan kasus pencemaran nama baik hakim Sarpin Rizaldi. Tidak cukup dengan itu saja, sekarang ini KPK diduga kuat dicoba untuk dilemahkan dari dalam, yaitu berkaitan dengan tindak laku kontraproduktif yang dilakukan Pimpinan KPK itu sendiri. 15

Sayangnya, setahun perjalanan masa pemerintahan Jokowi, belum tampak ada perubahan maupun ketegasan sikap untuk melawan upaya kriminalisasi Komisioner KPK, Bambang Widjojanto dan Abraham Samad, yang terjadi pasca penetapan Budi Gunawan sebagai tersangka. Kesan permisif terjadi ketika pelimpahan kasus penetapan Budi Gunawan dilakukan oleh KPK kepada Mabes Polri. Tidak mengherankan hasil akhirnya mudah ditebak. Pada akhirnya, kasus

15 Tempo Edisi “Aduh Ruki”, 14-20 Desember 2015. 
Budi Gunawan yang telah dilimpahkan ke Kejaksaan dan Kepolisian, dihentikan pada Maret 2015.16

Karut marut situasi penegakan hukum sebagaimana digambarkan di atas (baik dalam kaitan dengan pelanggaran hak asasi manusia maupun kasus-kasus korupsi) yang terjadi pasca pemerintahan otoritarian dan belum juga menunjukkan tanda-tanda akan surut dan dibereskan, pada akhirnya mengakibatkan gerakan bantuan hukum tergagap-gagap.

\section{Gerakan Bantuan Hukum: Rancang Ulang?}

Undang-Undang Nomor 16 Tahun 2011 sesungguhnya belum merefleksikan persepektif dan strategi yang diperlukan untuk melawan impunitas dan kemandekan penegakan hukum sebagaimana diuraikan di atas. Dalam catatan Makinara, Undang-Undang di atas belum maksimal memajukan upaya pemberian atau layanan bantuan hukum bagi masyarakat miskin. Dalam pandangannya, satu kelemahan utama dari Undang-Undang di atas adalah sifat atau tatanannya yang masih formalistik. Sekalipun layanan bantuan hukum adalah hak dari orang miskin yang sedianya dapat diperoleh tanpa bayar (pro bono publico), yakni sebagai penjabaran persamaan hak di hadapan hukum. Namun pada lain pihak, secara konseptual ternyata Undang-Undang Bantuan Hukum di atas baru mengkombinasikan beberapa ciri konsep bantuan hukum individual dengan beberapa ciri konsep bantuan struktural. Lagipula ciri bantuan hukum yang ditawarkan masih bersifat pasif (menunggu).

Dipandang dari perspektif sejarah, lembaga bantuan hukum tidak dapat dipisahkan dari peran utamanya sebagai motor penggerak gerakan bantuan hukum di Indonesia. Sekalipun yang digunakan adalah istilah 'bantuan', sesungguhnya bidang pekerjaan lembaga-lembaga bantuan hukum telah jauh berubah dan bergeser. Istilah yang lebih tepat sekarang ini sebagai pengganti kata bantuan adalah memberdayakan. Sebagai konsekuensinya, kerja lembaga-

16 Id. 
lembaga bantuan hukum tidak lagi berpusat semata pada advokasi korban, tetapi lebih jauh lagi, menjadi penggerak yang mendorong pembentukan sistem hukum yang demokratis.

Itu pula alasan mengapa di lingkungan lembaga-lembaga bantuan hukum dikembangkan apa yang dinamakan Pendidikan Hukum Kritis (PHK). PHK, meski terkesan sebagai bentuk pendidikan, sebenarnya adalah model gerakan alternatif yang tak semata bertumpu pada alternatif transfer pengetahuan, melainkan berupaya mendorong kekuatan publik dalam bentuk pengorganisasian rakyat. ${ }^{17}$ Alasannya adalah bahwa kerja lembaga bantuan hukum melalui PHK mensyaratkan adanya kemampuan pengorganisasian. Tujuannya adalah agar hasil dari pendidikan tersebut bisa dikembangkan menjadi gerakan kontrol (masyarakat) sipil yang efektif dalam rangka perlindungan dan pemenuhan hak-hak asasi manusia.

Gagasan inilah yang kemudian dirumuskan ke dalam model Bantuan Hukum Struktural (BHS) yang berkembang di awal 1980an. Bantuan Hukum Struktural, kala itu, muncul sebagai kritik atas gerakan bantuan hukum yang masih sangat terbatas (terfokus pada individu), dan lebih jauh lagi ingin mengubah bantuan hukum menjadi gerakan (reformasi) sosial. Mimpi BHS adalah mengubah tatanan sosial yang tidak manusia dan tidak adil. Itu sebabnya, gerakan bantuan hukum harus bisa membebaskan kaum tertindas dari praktek ketidakadilan sistem politik, hukum, ekonomi dan sosial-budaya.

Dalam perkembangan selanjutnya, lembaga-lembaga bantuan hukum mengupayakan muncul dan tumbunya aktor-aktor pembela hak asasi manusia atau penegak hukum yang mumpuni. Hal ini dilakukan terutama melalui kaderisasi pejuang hukum yang sekaligus dididik untuk menjadi penggerak kekuatan sosial masyarakat: aktivis paralegal. Para-legalisme, dikombinasikan dengan model pemberdayaan - alih-alih sekadar bantuan - hukum, menjadi pendorong

\footnotetext{
${ }^{17}$ Rikardo Simarmata.“Pendidikan Hukum Kritis: Asal-Usul, Faham, Prinsip dan Metode”, Jurnal Hukum Jentera, Edisi Khusus, 2003.
} 
perubahan situasi sosial yang secara struktural tidak berkeadilan. Paralegal, sebagaimana muncul dalam perjalanan panjang kerja lembaga-lembaga bantuan hukum, memainkan peran penting dalam menfasilitasi pembentukan organisasi rakyat, mendidik, melakukan penyadaran, melakukan analisis sosial, advokasi, membantu pengacara, memediasi dan mengumpulkan dokumentasi. ${ }^{18}$

Sekalipun demikian, bantuan hukum struktural tidak sempurna. Suatu analisis menyebut dua kegagalan bantuan hukum struktural. Pertama, penjabaran gagasan bantuan hukum struktural dinilai kurang jelas, sehingga melahirkan berbagai tafsir di lapangan; Kedua, bantuan hukum struktural ternyata terjebak dalam bantuan hukum gaya lama karena dalam kenyataan tidak berhasil membangun institusi atau organisasi alternatif di tingkat basis. ${ }^{19}$ Belakangan, gagasan bantuan hukum struktural dianggap tidak lagi mampu menjawab persoalan kegagalan sistem penegakan hukum yang sebelumnya digambarkan di atas.

Situasi seperti di atas masih muncul dan dirasa di masa awal pasca tumbangnya rezim otoritarian Soeharto di pertengahan 1998. Politik hukum yang sejak itu berkembang memang terasa berbeda, akibat pengaruh proyek reformasi hukum yang sejak itu dicanangkan. Tanda-tanda perubahan positif di bidang reformasi hukum tampak dari, antara lain: terakomodasinya hak-hak asasi manusia dalam hukum/perundang-undangan, termasuk pencantumannya sebagai hak-hak dasar (constitutional rights); kebebasan pers dijamin hukum sehingga tidak lagi terbuka peluang pembredelan, sensor dan pencabutan perijinan bagi pers; liberalisasi sistem politik dan penyelenggaraan pemerintahan, terutama dalam wujud pergeseran sentralisasi menjadi desentralisasi serta pengembangan budaya demokrasi elektoral di tingkat nasional maupun lokal; pembagian porsi kekuasaan antara eksekutif, legislatif dan yudisial, diikuti dengan pembatasan kekuasan Presiden/Wakil Presiden; serta sejumlah bentuk paket reformasi di

\footnotetext{
18 Id, hlm. 35.

${ }^{19} \mathrm{Id}, \mathrm{hlm} .37$.
} 
tubuh peradilan, kepolisian, kejaksaan, dan dukungan legalisasi perundangundangan yang menyangkut pula hak-hak asasi manusia.

Semestinya, dengan reformasi hukum yang sedemikian maju, pelaksanaan beban kerja lembaga-lembaga bantuan hukum menjadi jauh lebih ringan. Faktanya? Ternyata, reformasi hukum yang 'dinilai positif' itulah yang justru melanggengkan situasi yang serupa dengan apa yang muncul pada zaman Presiden Soeharto. Suatu masa di mana hukum begitu gampangnya dilemahkan, diskriminatif dan berkarakter melegitimasi pelanggaran hak asasi manusia maupun praktik korupsi. Dengan kata lain, reformasi (hukum) yang terjadi awal 2000 gagal mencapai sasarannya, bahkan memunculkan situasi yang lebih buruk, hal mana sudah diuraikan pada bagian awal tulisan ini.

Persoalan yang dapat kita ajukan di sini adalah apakah, mengingat kontradisksi di atas antara reformasi hukum dan situasi hukum yang masih ada sekarang ini, kerja lembaga-lembaga bantuan hukum selama ini perlu di re-evaluasi? Ataukah alternatifnya adalah mendorong lembaga-lembaga bantuan hukum untuk lebih memusatkan waktu dan enersinya pada penguatan gerakan politik untuk mendorong percepatan transformasi hukum menjadi lebih berkeadilan?

Tentunya, tulisan singkat ini tidak akan begitu saja diakhiri dengan preskripsi tertentu yang dimaksud sebagai panduan untuk merancang strategi lembaga bantuan hukum di masa depan. Berkaitan dengan itu ada dua hal yang harus dicermati. Pertama, konteks politik nasional dan lokal haruslah disimak dan dibaca kritis oleh para pekerja lembaga-lembaga bantuan hukum itu sendiri (atau pekerja bantuan hukum (para-legal), yang ternyata tidak semuanya adalah pengacara/advokad). Hanya mereka-lah yang berada dalam posisi untuk dapat memahami situasi-kondisi yang ada secara tepat dan sekaligus menjajaki peluangpeluang yang terbuka untuk mengubahnya ke arah yang lebih baik. Kedua, lembaga-lembaga bantuan hukum harus secara mumpuni memetakan kekuatankekuatan sosial-politik yang kini tumbuh pesat seiring dengan jatuhnya rezim 
pemerintahan Presiden Soeharto. Hal ini harus dilakukan terutama dengan menganalisis peran yang dimainkan organisasi masyarakat sipil, mengidentifikasi kantong-kantong gerakan sosial yang efektif, sekaligus merefleksikan kasus-kasus yang selama ini ditangani lembaga-lembaga bantuan hukum.

Apa yang juga bisa menjadi titik tolak adalah pengakuan akan gagalnya organisasi masyarakat sipil, termasuk lembaga-lembaga bantuan hukum, dalam mereformasi dan membangun hukum yang berkeadilan. Bahkan bisa dan kerap terjadi justru lembaga-lembaga bantuan hukum berubah menjadi makelar proyekproyek bantuan hukum yang diprakarsai dan didanai Bank Dunia atau organisasiorganisasi proponen Neo-Liberal. Padahal justru lembaga-lembaga itu ditengarai, setidak-tidaknya diduga keras, merupakan aktor di belakang gagalnya reformasi hukum yang dicanangkan pasca Soeharto. Hal lain yang berkaitan dengan itu adalah kegagalan gerakan masyarakat sipil untuk memahami, mencermati apalagi menghindar dari strategi program-program pemajuan hak-hak asasi manusia yang berada dan berkembang dalam paradigma liberalisasi pasar (market friendly human rights paradigm).

Selain itu, perluasan pergerakan lembaga-lembaga bantuan hukum tidak atau jangan lagi terpusat di luar kampus. Justru yang harus diperkuat dan diperluas jaringan kerja dan kemampuannya adalah lembaga-lembaga bantuan hukum yang terpusat di kampus (terafiliasi dengan fakultas hukum). Hal ini bisa dimulai dengan membangun sistem kerja dan evaluasi kerja advokasi. ${ }^{20}$ Persoalan akses keadilan, bukan semata penting dibaca sebagai penyediaan jaminan akses formal, melainkan harus ditempatkan dalam konteks sosial politik yang melingkupinya. Sejalan dengan itu, pendidikan tinggi hukum sudah seharusnya meninggalkan metoda pengajaran hukum yang terpusat pada aturan hukum tertulis (yuridis-

\footnotetext{
${ }^{20}$ Fulthoni, Siti Aminah, dan Uli Parulian Sihombing. Mengelola Legal Clinic. Panduan Membentuk dan Mengembangkan LBH Kampus untuk Memperkuat Akses Keadilan (ILRC/The Indonesian Legal Resource Center dan CIDA, Jakarta, 2009).
} 
normatif atau dogmatis) dan melengkapinya dengan metoda-metoda yang lebih membuka diri pada analisis sosial terhadap hukum.

Alih-alih mempertahankan dan menjaga sikap kritis, dalam perkembangannya, lembaga-lembaga bantuan hukum terlalu mudah mengalah pada pragmatism kebutuhan pendanaan melalui proyek atau program. Dalih utama adalah perlunya organisasi bertahan hidup. Namun dalam proses yang sama, idealisme aktivisme sosial-politik yang seharusnya diemban lembagalembaga bantuan hukum justru ditinggalkan. Hal serupa sayangnnya tejadi juga di sejumlah negara-negara dunia ketiga lainnya.

\section{Penutup}

Gerakan sosial politik lembaga-lembaga bantuan hukum sekarang ini terus memerlukan pasokan enersi politik yang tidak kecil. Lembaga-lembaga itu harus semakin cermat mengembangkan strategi agar terus dapat mendorong transformasi sistem politik maupun hukum ke arah yang lebih baik. Dimaksud dengan itu adalah sistem yang lebih dan kian berpihak pada rakyat dan perlindungan-penegakan hak asasi manusia. Gerakan transformasi hukum yang berkeadilan hanya bisa dan mungkin tercapai melalui pengembangan modelmodel bantuan hukum yang baru. Dalam pada itu bantuan hukum itu harus disinergikan dengan pengembangan gerakan sosial-politik melalui organisasi masyarakat yang kuat, terkonsolidasi, kritis dan berani melakukan perubahan sistem, termasuk bila perlu, dengan menggunakan metode ekstra-legal sekalipun.

Sekalipun begitu, harus dicermati bahwa gerakan bantuan hukum yang berkembang saat ini, dengan adanya Undang-Undang Bantuan Hukum, akan mudah dan cenderung terjebak pada pragmatisme. Hal ini kiranya tidak terhindarkan. Bilamana strata sosial yang menjadi sasaran tidak diperhitungkan dengan tepat, maka dengan mudah gerakan bantuan hukum hanya akan menyentuh wilayah permukaan dan gagal melihat akar masalah. Lebih dari itu, harus pula diwaspadai perangkap Neo-Liberalisme. Bilamana ini terjadi, program bantuan hukum alih-alih mampu mencerdaskan atau membuat melek hukum 
masyarakat terpinggirkan. Sebaliknya yang terjadi, yaitu orientasi kerja lembagalembaga bantuan hukum justru memperkuat sistem atau bangunan kekuasaan sosial-politik yang bersifat menindas.

Berdasarkan itu semua, maka diperlukan reorientasi gerakan bantuan hukum. Tantangan yang dilempar pada pengacara publik atau pengabdi bantuan hukum adalah untuk melampaui mandat yang diberikan pada mereka oleh Undang-Undang Nomor 16 Tahun 2011 tentang Bantuan Hukum. Sekaligus, mereka harus berani mengambil posisi dan melawan diskursus sekaligus paradigma hak asasi manusia yang ramah pada kepentingan pasar. Tulisan ini akan diakhiri dengan kutipan dari tulisan yang dibuat seorang buruh:

"...bahwa hari ini, menyelesaikan masalah hukum hanya bisa dituntaskan bukan dengan cara berhukum yang sehat, apalagi mengandalkan institusi politik dan hukum bekerja baik, melainkan menjawabnya dengan gerakan sosial nan terkonsolidasi untuk merebut hak-hak asasi manusia. Meskipun beresiko tinggi, rasanya jauh lebih efektif, terukur dan lugas dengan strategi ini di tengah ketidakberpihakan pemerintah dan kaum pemodal."

Akhir kata, dengan mencermati situasi-kondisi masih mendominasinya kekuatan politik ekonomi yang tidak berpihak pada upaya perlindungan hak-hak asasi manusia, maka di masa depan, reorientasi gerakan bantuan hukum yang dimotori para pengacara publik sudah seharusnya ditujukan pada ikhtiar membangun sistem hukum yang lebih berkeadilan sosial. 


\section{Daftar Pustaka}

Buku:

Adnan Buyung Nasution. Bantuan Hukum di Indonesia. (LP3ES, Jakarta, 1981)

Fulthoni, Siti Aminah, dan Uli Parulian Sihombing. Mengelola Legal Clinic. Panduan Membentuk dan Mengembangkan LBH Kampus untuk Memperkuat Akses Keadilan (ILRC/The Indonesian Legal Resource Center dan CIDA, Jakarta, 2009).

Gerry Van Klinken and E. Aspinall. The state and illegality in Indonesia. (Brill, Leiden, 2011).

Herbin M. Siahaan (ed.). Pemberdayaan Hukum Untuk Meningkatkan Tata Pemerintahan Yang Baik Dan Mengurangi Kemiskinan (The Asia Foundation dan Asian Developing Bank, Jakarta, 2003).

Herlambang P. Wiratraman. "Disain Neo-Liberalisme dan Ancaman Terhadap HakHak Buruh", Makalah Untuk Labor Law Course For Trade Unionist, Training, Surabaya, 7-10 September 2006, Trade Union Rights Center Dan Forum Buruh Surabaya (2006).

Herlambang P. Wiratraman. Good Governance and Legal Reform in Indonesia. (OHRSD Mahidol University, Bangkok, 2007).

Herlambang P. Wiratraman. "Neo-Liberalisme, Good Governance dan Hak Asasi Manusia”, Jurnal Hukum Jentera XV, Januari-Maret (2007).

Herlambang P. Wiratraman. “Gagalnya Penegakan Hukum dan HAM”, Kompas, 30 September (2011).

Herlambang P. Wiratraman dan M. Yasin (ed) Panduan Bantuan Hukum di Indonesia (Ausaid-YLBHI, Jakarta, 2014)

Ihdi Karim Makinara. "Pengaruh Bantuan Hukum terhadap Masyarakat Miskin (Meninjau Undang-Undang Nomor 16 Tahun 2011 tentang Bantuan Hukum)”. Rechtsvinding (BPHN), Volume 2 Nomor 1, April (2013).

Jan Naderveen Pieterse. Globalization or Empire? (Routledge, New York/London, 2004).

Margaret Schuler dan Shakuntala Kadirgamar-Rajashingham (ed.). Legal Literacy: A Tool for Women's Empowerment. (UNIFEM, New York, 1992).

Moch. Zaidun "Gerakan bantuan hukum struktural di Indonesia: studi tentang tipologi gerakan bantuan hukum struktural Yayasan LBH Indonesia". M.Si. Tesis. Surabaya : Program Pascasarjana, Universitas Airlangga, 1996.

Rikardo Simarmata."Pendidikan Hukum Kritis: Asal-Usul, Faham, Prinsip dan Metode", Jurnal Hukum Jentera, Edisi Khusus (2003)

Soetandyo Wignjosoebroto. Hukum dalam Masyarakat. (Graha Ilmu, Yogjakarta, 2013).

Todung Mulya Lubis. Bantuan Hukum dan Kemiskinan Struktural (LP3ES, Jakarta, 1986)

Todung Mulya Lubis. "Gerakan Bantuan Hukum Di Indonesia: Sebuah Studi Awal" dalam Abdul Hakim Garuda Nusantara dan Mulyana W. Kusumah, Be- 
berapa Pemikiran Mengenai Bantuan Hukum: Ke arah Bantuan Hukum Struktural (Alumni, Bandung, 1990).

Todung Mulya Lubis. "Bantuan Hukum: Ar $\square$ ah dan Peranannya”, Prisma No. 6 Tahun II, Desember 1973.

Vedi R. Hadiz. "Local Power: Decentralization and political reorganization in Indonesia," conference paper, presented at the "Globalization, Conflict, and Political Regimes in East and Southeast Asia," (Asia Research Center, Murdoch University, Western Australia, 15-16 August 2003).

Vedi R Hadiz. "The Localization of Power in Southeast Asia," Democratization, 14:5, 873-892, (2007).

Vedi R. Hadiz. Localising Power in Post-Authoritarian Indonesia: A Southeast Asia Perspective. (Stanford University Press, Stanford, 2010).

YLBHI-LBH Semarang. Catatan Akhir Tahun 2015: Membunyikan Lonceng Kematian (LBH Semarang, Semarang, 2015).

\section{Media Massa}

Tempo, Edisi “Aduh Ruki”, 14-20 Desember (2015). 